Article

\title{
Accelerating photocatalytic hydrogen evolution and pollutant degradation by coupling organic co-catalysts with $\mathrm{TiO}_{2}$
}

\author{
Jun Shen a, $\dagger$, Rui Wang b,†, Qinqin Liu b,*, Xiaofei Yang c, Hua Tang b, Jin Yang b \\ a School of Pharmacy, Suzhou Vocational Health College, Suzhou 215009, Jiangsu, China \\ b School of Materials Science and Engineering, Jiangsu University, Zhenjiang 212013, Jiangsu, China \\ c Department of Chemistry, College of Science, Nanjing Forestry University, Nanjing 210037, Jiangsu, China
}

\section{A R T I C L E I N F}

\section{Article history:}

Received 31 August 2018

Accepted 21 September 2018

Published 5 March 2019

\section{Keywords:}

$\mathrm{TiO}_{2}$

Oxamide

Co-catalyst

Photocatalysis

Hydrogen evolution

Dye degradation

\begin{abstract}
A B S T R A C T
Accelerating the separation efficiency of photoexcited electron-hole pairs with the help of highly active co-catalysts has proven to be a promising approach for improving photocatalytic activity. Thus far, the most developed co-catalysts for semiconductor-based photocatalysis are inorganic materials; the employment of a specific organic molecule as a co-catalyst for photocatalytic hydrogen evolution and pollutant photodegradation is rare and still remains a challenging task. Herein, we report on the use of an organic molecule, oxamide (OA), as a novel co-catalyst to enhance electron-hole separation, photocatalytic $\mathrm{H}_{2}$ evolution, and dye degradation over $\mathrm{TiO}_{2}$ nanosheets. OA-modified $\mathrm{TiO}_{2}$ samples were prepared by a wet chemical route and demonstrated improved light absorption in the visible-light region and more efficient charge transport. The photocatalytic performance of $\mathrm{H}_{2}$ evolution from water splitting and rhodamine $\mathrm{B}(\mathrm{RhB})$ degradation for an optimal OA-modified $\mathrm{TiO}_{2}$ photocatalyst reached $2.37 \mathrm{mmol} \mathrm{g}-1 \mathrm{~h}^{-1}$ and $1.43 \times 10^{-2} \mathrm{~min}^{-1}$, respectively, which were 2.4 and 3.8 times higher than those of pristine $\mathrm{TiO}_{2}$, respectively. A possible mechanism is proposed, in which the specific $\pi$-conjugated structure of $\mathrm{OA}$ is suggested to play a key role in the enhancement of the charge transfer and catalytic capability of $\mathrm{TiO}_{2}$. This work may provide advanced insight into the development of a variety of metal-free organic molecules as functional co-catalysts for improved solar-to-fuel conversion and environmental remediation.
\end{abstract}

(C) 2019, Dalian Institute of Chemical Physics, Chinese Academy of Sciences. Published by Elsevier B.V. All rights reserved.

\section{Introduction}

With the rapid growth of industry worldwide, energy shortages and environmental pollution have become the most challenging and urgent problems. Photocatalytic $\mathrm{H}_{2}$ generation or pollutant removal by sunlight provides one of the most promising ways to address this issue, but the key is to develop efficient photocatalysts with high activity and low cost [1-6].
Among various semiconductor-based photocatalysts, $\mathrm{TiO}_{2}$, which has good physicochemical stability, has received the greatest attention as it can be widely applied in $\mathrm{H}_{2}$ generation, $\mathrm{CO}_{2}$ reduction, and organic-pollutant degradation [7-16]. However, the fast recombination of photogenerated carriers resulting from the Coulomb force remains a critical factor that restricts its photocatalytic efficiency [17-21].

In the past decade, immense effort has been invested to

\footnotetext{
* Corresponding author. Tel: +86-511-88790191; Fax: +86-511-88790195; E-mail: liu_qin_qin@126.com

†These authors contributed equally to this work.

This work was supported by the National Natural Science Foundation of China $(51672113,51602132)$, the Six Talent Peaks Project in Jiangsu Province (2015-XCL-026), the Natural Science Foundation of Jiangsu Province (BK20171299), the Training Project of Jiangsu University for Young Cadre Teachers (5521220009), and the Youth Research Project of Jiangsu Health and Family Planning Commission in 2016 (Q201609). DOI: 10.1016/S1872-2067(18)63166-3 | http://www.sciencedirect.com/science/journal/18722067 | Chin. J. Catal., Vol. 40, No. 3, March 2019
} 
eliminate the aforementioned obstacles, including the incorporation of co-catalysts, doping, surface modification, and fabricating composite systems [22-30]. Among these approaches, loading co-catalysts is widely recognized to be promising and facile, and which simultaneously results in enhanced light utility, promoted charge separation, and improved $\mathrm{H}_{2}$-generation kinetics. Thus far, various co-catalysts, including noble metals (e.g., Au [31,32], Pt [33], and Pd [34]) and inorganic compounds (e.g., Ni(OH) 2 [35], $\mathrm{MoS}_{2}$ [36,37], and CoP [38]), have been explored and loaded onto $\mathrm{TiO}_{2}$ with the aim of enhancing the photocatalytic performance. However, the practical applications are still constrained by the high cost or harsh synthetic procedures of noble-metal-based co-catalysts. Therefore, it is highly desirable to develop more suitable co-catalysts in order to produce more efficient photocatalysts.

Recently, organic co-catalysts with exciting characteristics, for example those that are metal-free, cost-effective, and have easily adjustable properties via modification of functional groups, have seen impressive achievements in improving the photocatalytic performance [39,40]. Choi et al. [41] incorporated dopamine with $\mathrm{TiO}_{2}$ and found that dopamine as a co-catalyst could form a more efficient surface complex on the $\mathrm{TiO}_{2}$ surface, thus improving the photocatalytic performance. Chen et al. [42] proved that poly(benzothiadiazole) could be conjugated with $\mathrm{TiO}_{2}$ to improve visible-light-driven $\mathrm{H}_{2}$ production and pollutant removal.

Herein, for the first time, oxamide (OA) was used as a co-catalyst. $\mathrm{OA}$ was decorated on $\mathrm{TiO}_{2}$ nanosheets and the material was investigated as a novel photocatalyst for water splitting and dye decomposition. The OA with delocalized $\pi$-conjugated structures resulted in fast photogenerated charge separation and diminished the recombination rate. Accordingly, the $\mathrm{TiO}_{2}-\mathrm{OA}$ hybrid exhibited higher efficiency for $\mathrm{H}_{2}$ production and dye degradation. The present work is expected to provide new insights into the development of organic co-catalysts and the construction of environmentally friendly photocatalysts for applications in energy conversion and environmental purification.

\section{Experimental}

\subsection{Synthesis of photocatalyst}

All raw materials were analytical reagents and were used without further purification. Firstly, $5 \mathrm{~mL}$ of tetrabutyl titanate (98\%) was dissolved in $50 \mathrm{~mL}$ of $\mathrm{H}_{2} \mathrm{O}$, and then $1 \mathrm{~mL}$ of hydrofluoric acid (HF, 40\%) was added dropwise into the above stirred solution. Subsequently, the resulting solution was transferred to a Teflon-lined autoclave and heated at $200{ }^{\circ} \mathrm{C}$ for $24 \mathrm{~h}$ [43]. After cooling to room temperature, the as-prepared $\mathrm{TiO}_{2}$ nanosheets were washed and dried in an electric oven at $60{ }^{\circ} \mathrm{C}$ overnight. $\mathrm{TiO}_{2}-\mathrm{OA}$ hybrid samples were fabricated by a wet chemical route. In a typical process, $0.5 \mathrm{~g}$ of the as-prepared $\mathrm{TiO}_{2}$ nanosheets and the corresponding amount for different weight ratios $(5,10,30$, and $50 \mathrm{wt} \%)$ of $\mathrm{OA}$ were added into $10 \mathrm{~mL} \mathrm{H}_{2} \mathrm{O}$ and stirred for $12 \mathrm{~h}$ to enable $\mathrm{OA}$ and $\mathrm{TiO}_{2}$ to form effective interface contact; the $\mathrm{pH}$ value for the suspension was 3 . Then, the whole solution was centrifuged and heated at $80{ }^{\circ} \mathrm{C}$ for $2 \mathrm{~h}$. Finally, the samples were collected and then labeled as TOA- $x$, in which the $x$ is the weight ratio of $\mathrm{OA}$ in $\mathrm{TiO}_{2}$.

\subsection{Characterization}

Powder X-ray diffraction (XRD) patterns were acquired via a Bruker D8 Advance X-ray diffractometer with $\mathrm{Cu} K_{\alpha}(\lambda=$ $0.15406 \mathrm{~nm}$ ). The morphology of the products was observed via scanning electron microscopy (SEM, JEOL JXA-840A) and transmission electron microscopy (TEM, Japan JEM-100CX II100 kV). X-ray photoelectron spectra (XPS) and valence-band X-ray photoelectron spectra (VBXPS) were obtained by a PHI-5000C system. UV-visible diffused reflectance spectra were obtained using a UV-visible spectrophotometer (UV2550, Japan Shimadzu). A fluorescence spectrophotometer (Hitachi, F-7000) and an electrochemical station (Chenhua Instruments, CHI660D) were used to record the photoluminescence (PL) spectra and photocurrent. The electron spin resonance (ESR) measurements were carried out on a JES FA200 spectrometer with 5,5-dimethyl-1-pyrroline- $N$-oxide (DMPO) as the radical-capture reagent.

\subsection{Photocatalytic hydrogen evolution}

Photocatalytic $\mathrm{H}_{2}$-evolving was performed in a closed system equipped with a $300 \mathrm{~W}$ Xe lamp (PLS-SXE 300C). Typically, $10 \mathrm{mg}$ of the photocatalyst and $10 \mathrm{~mL}$ of triethanolamine were dispersed in $90 \mathrm{~mL}$ of $\mathrm{H}_{2} \mathrm{O}$ with $80 \mu \mathrm{L}$ of $\mathrm{H}_{2} \mathrm{PtCl}_{6}$ as the co-catalyst. The $\mathrm{H}_{2}$ evolution was monitored through a gas chromatograph (GC D7900P, TCD detector).

\subsection{Photocatalytic degradation of organic dyes}

Methylene blue (MB) and rhodamine B (RhB) were selected as the dyes for photocatalytic degradation characterization using a 300W Xe lamp. In each run, $15 \mathrm{mg}$ of solid catalysts were well dispersed in $30 \mathrm{~mL}$ of an aqueous solution containing a certain amount of organic dyes $\left(10 \mathrm{mg} \mathrm{L}^{-1}\right)$, and then the whole suspension was stirred in a dark environment for $30 \mathrm{~min}$ to reach adsorption-desorption equilibrium. A certain amount of the suspension was extracted to record the variations of maximum absorption of dye (552 $\mathrm{nm}$ for $\mathrm{RhB}$ and $664 \mathrm{~nm}$ for MB). The rates of the photocatalytic degradation were calculated using the equation $\eta=C_{\mathrm{t}} / C_{0} \times 100 \%$.

\section{Results and discussion}

The photocatalytic performance of the as-synthesized products was measured by hydrogen evolution under visible-light irradiation. As shown in Fig. 1, the $\mathrm{TiO}_{2}-\mathrm{OA}$ hybrids demonstrate higher photocatalytic $\mathrm{H}_{2}$-generation efficiency than pristine $\mathrm{TiO}_{2}$, indicating that the OA co-catalyst can promote the photocatalytic water-splitting activity of $\mathrm{TiO}_{2}$. Besides that, a suitable content of OA co-catalyst is crucial for enhancing the performance. Among all $\mathrm{TiO}_{2}-\mathrm{OA}$ composites, TOA-30 

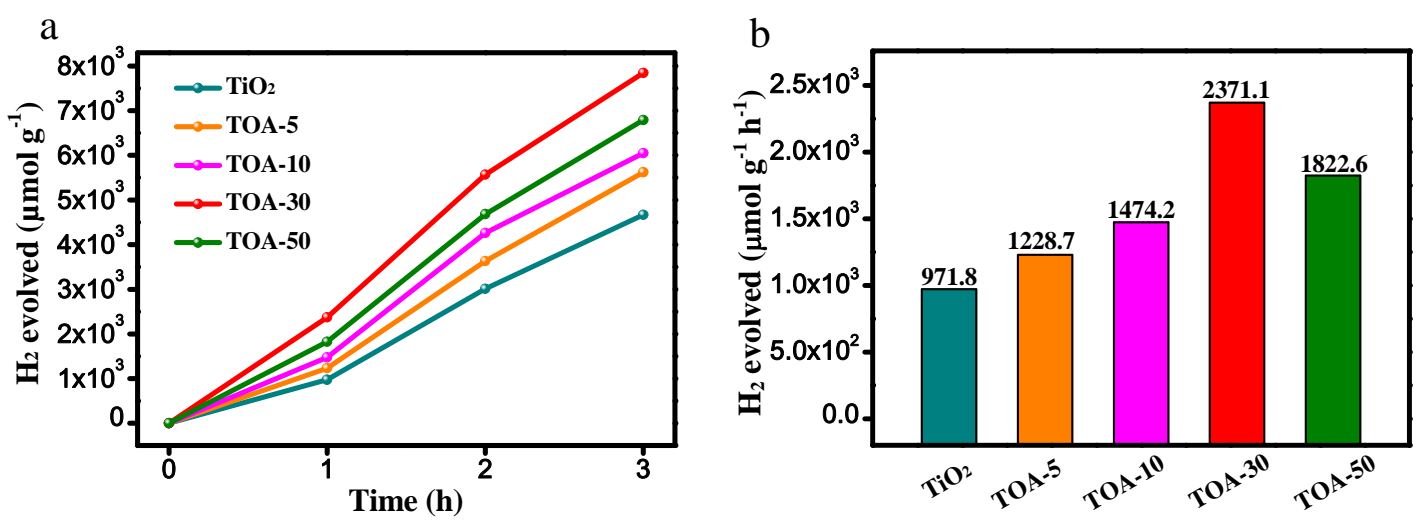

Fig. 1. (a) Photocatalytic $\mathrm{H}_{2}$-production and (b) $\mathrm{H}_{2}$-evolving rates over pure $\mathrm{TiO}_{2}$ and $\mathrm{TiO}_{2}-\mathrm{OA}$ samples.

performs the best, with a $\mathrm{H}_{2}$-generation rate of $2371.1 \mu \mathrm{mol} \mathrm{g}-1$ $\mathrm{h}^{-1}$, which is 2.4 times higher than that of pristine $\mathrm{TiO}_{2}(971.8$ $\mu \mathrm{mol} \mathrm{g} \mathrm{g}^{-1} \mathrm{~h}^{-1}$ ). However, excessive loading of the $\mathrm{OA}$ co-catalyst results in a decrease in $\mathrm{H}_{2}$-generation; the $\mathrm{H}_{2}$-generation rate of TOA-50 is reduced to $1822.6 \mu \mathrm{mol} \mathrm{g}-1 \mathrm{~h}^{-1}$, which is because the excess co-catalyst may overlap with the active sites of $\mathrm{TiO}_{2}$ and impair the photocatalytic activity [44].

The TOA-30 sample, with the highest photocatalytic performance, was then chosen as the optimal photocatalyst for the following characterizations. The morphologies of $\mathrm{TiO}_{2}$ and TOA-30 are shown in SEM and TEM images (Fig. 2). Pristine $\mathrm{TiO}_{2}$ has square-like nanosheets with an average size of $50 \mathrm{~nm}$ (Fig. 2a and 2b), and the TOA-30 hybrid still exhibits this nanosheet-like morphology (Fig. 2c and 2d). EDX element-mapping pictures for TOA-30 shown in Fig. 2e prove that the $\mathrm{Ti}$ and $\mathrm{O}$ elements are uniformly distributed while a small amount of $\mathrm{C}$ and $\mathrm{N}$ elements are scattered on the surface of $\mathrm{TiO}_{2}$. The HRTEM image shown in Fig. $2 \mathrm{f}$ reveals that the interplanar distance of the $\mathrm{TiO}_{2}$ nanosheet is $0.35 \mathrm{~nm}$, corresponding to the $d$-spacing of (101) lattice planes of $\mathrm{TiO}_{2}$ [45].

The crystal structure and chemical states of the $\mathrm{TiO}_{2}$ and $\mathrm{TiO}_{2}-\mathrm{OA}$ hybrids were characterized by XRD and XPS. For pristine $\mathrm{TiO}_{2}$ (Fig. 3a), all diffraction peaks could be indexed to anatase $\mathrm{TiO}_{2}$ (JCPDS 21-1272). No difference of diffraction peaks is observed after incorporating the $\mathrm{OA}$ co-catalysts, indicating that the OA may exist in amorphous form. The elements Ti and 0 , with the binding energies of $458 \mathrm{eV}$ ( Ti $2 p$ ) and $531 \mathrm{eV}(\mathrm{O}$ 1s), exist in both $\mathrm{TiO}_{2}$ and $\mathrm{TOA}-30$ (Fig. 3b). For the high-resolution $\mathrm{Ti} 2 p$ spectrum of $\mathrm{TiO}_{2}$ (Fig. 3c), two peaks centered at 458.8 and $464.5 \mathrm{eV}$ are assigned to $\mathrm{Ti} 2 p_{3 / 2}$ and $\mathrm{Ti}$ $2 p_{1 / 2}$, respectively, indicating an oxidation state of $\mathrm{Ti}^{4+}$. These two $\mathrm{Ti}^{4+}$ peaks in $\mathrm{TiO}_{2}-\mathrm{OA}$ show a slight shift towards low binding energies. The valence of the $\mathrm{O}$ element in $\mathrm{TiO}_{2}$ and $\mathrm{TiO}_{2}-\mathrm{OA}$ is reflected by $\mathrm{O} 1 \mathrm{~s}$ XPS spectra (Fig. $3 \mathrm{~d}$ ), in which the main peak at $530 \mathrm{eV}$ is assigned to Ti-0-Ti linkages while the shoulder peak at $531.4 \mathrm{eV}$ is caused by the $-\mathrm{OH}$ of adsorbed $\mathrm{H}_{2} \mathrm{O}$ molecules [46]. For TOA-30 (Fig. 3e), three binding energies of $\mathrm{C} 1 s$ at 284.8, 286.5, and $288.6 \mathrm{eV}$, corresponding respectively to $\mathrm{C}-\mathrm{C}, \mathrm{C}-\mathrm{N}$, and $\mathrm{C}=\mathrm{O}$, are observed. The $\mathrm{N} 1 \mathrm{~s}$ spectrum (Fig. 3f) of TOA-30 show peaks representing the $\mathrm{O}=\mathrm{C}-\mathrm{NH}_{2}$ bond at $401.2 \mathrm{eV}$, the $\mathrm{C}-\mathrm{N}$ bond at $399.8 \mathrm{eV}$, and the Ti-NHbond at $398.1 \mathrm{eV}$ [40]. These results indicate that the OA co-catalyst exists on the surface of $\mathrm{TiO}_{2}$ and the appearance of the Ti-NH- bond indicates that the $\mathrm{NH}_{2}$ group may form a covalent interaction with the $\mathrm{TiO}_{2}$ surface.

As further proof of the above viewpoint, FTIR and TG experiments were carried out and the results are shown in Fig. $4 \mathrm{a}$ and $4 \mathrm{~b}$, respectively. For bare $\mathrm{TiO}_{2}$, the broad absorption band at $350-750 \mathrm{~cm}^{-1}$ [41] is assigned to Ti-O stretching while the bands at 3444 and $1625 \mathrm{~cm}^{-1}$ are ascribed to $\mathrm{H}-\mathrm{O}-\mathrm{H}$ moieties and bending of $\mathrm{H}-\mathrm{O}$ of adsorbed $\mathrm{H}_{2} \mathrm{O}$, respectively $[47,48]$. For pure $\mathrm{OA}$, the presence of amine groups is evidenced by characteristic N-H stretching vibrations at 3181 and $3374 \mathrm{~cm}^{-1}, \mathrm{~N}-\mathrm{H}$ wobble vibrations at 794 and $1115 \mathrm{~cm}^{-1}$, a C=0 stretching vibration around $1654 \mathrm{~cm}^{-1}$, as well as a $\mathrm{C}-\mathrm{N}$ bending vibration at $1350 \mathrm{~cm}^{-1}$ [49]. The $\mathrm{TiO}_{2}-\mathrm{OA}$ sample exhibits a $\mathrm{C}=0$ stretching vibration at $1662 \mathrm{~cm}^{-1}$ and two strong $\mathrm{N}-\mathrm{H}$ stretchings at 3186 and $3385 \mathrm{~cm}^{-1}$. The peaks in the hybrid composite exhibit a red shift compared to bare $\mathrm{OA}$, indicating that a conjugated

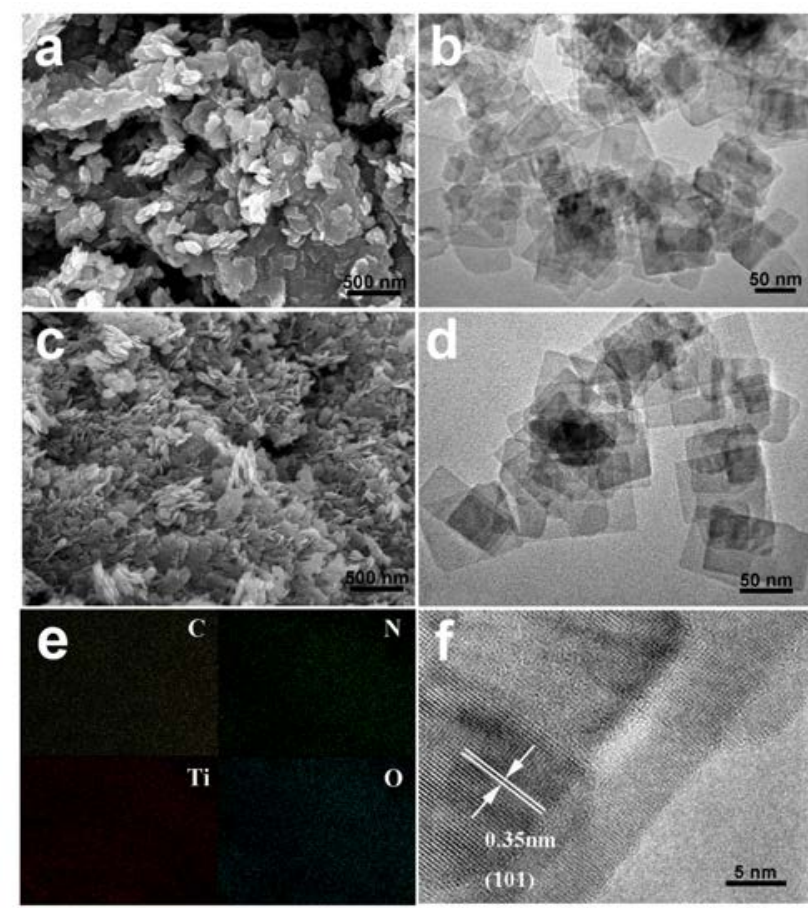

Fig. 2. SEM and TEM images of (a, b) pure $\mathrm{TiO}_{2}$ and (c, d) TOA-30; (e) EDX mapping of Ti, O, C, and N elements; (f) HRTEM image of TOA-30. 

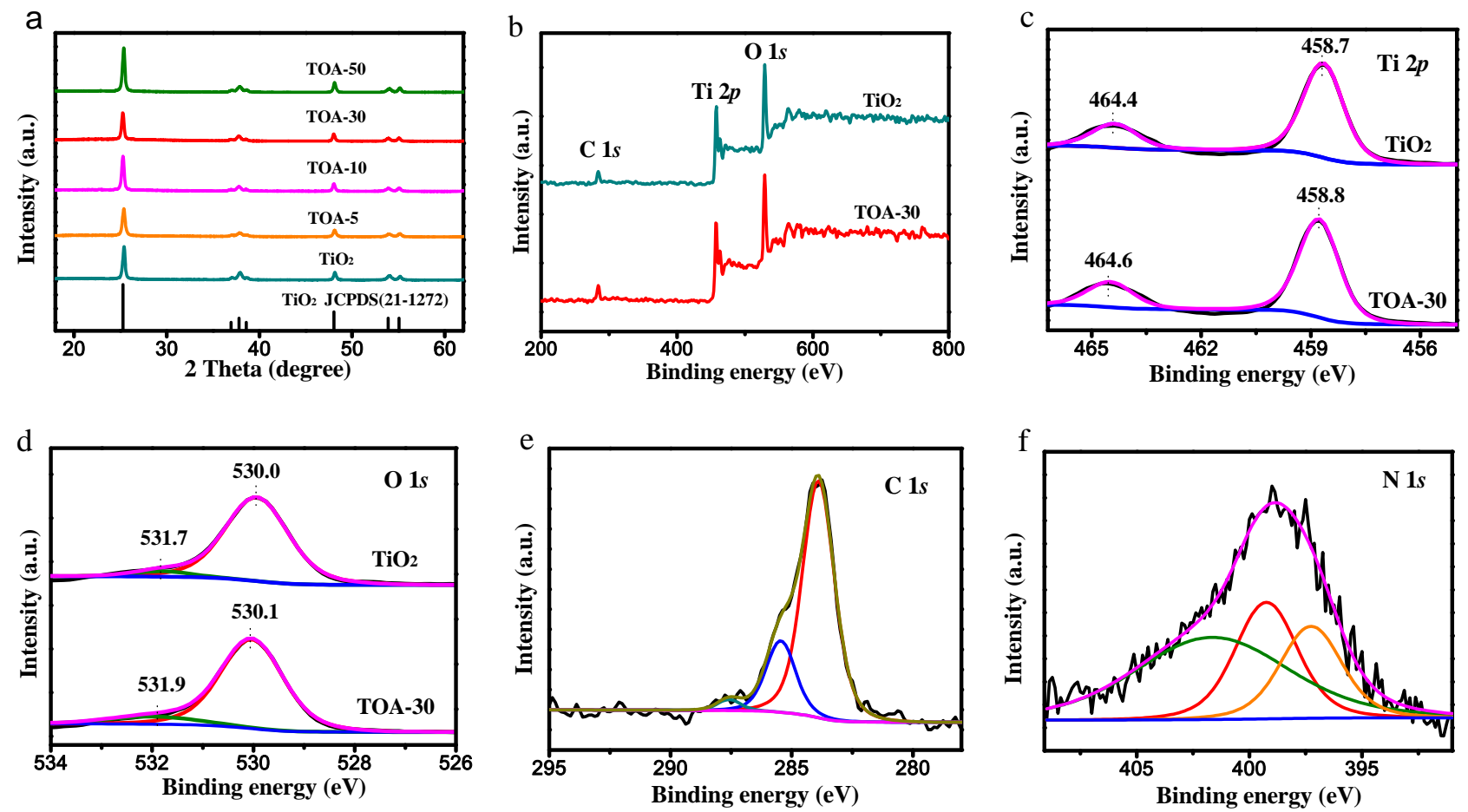

Fig. 3. (a) XRD patterns of $\mathrm{TiO}_{2}$ and $\mathrm{TiO}_{2}-\mathrm{OA}$ composites with different ratios; (b) survey XPS spectra; high-resolution XPS spectra of (c) Ti $2 p$ and (d) $01 s$ for $\mathrm{TiO}_{2}$ and $\mathrm{TOA}-30$; high-resolution XPS spectra of (e) $\mathrm{C} 1 s$ and (f) $\mathrm{N} 1 s$ for TOA-30.
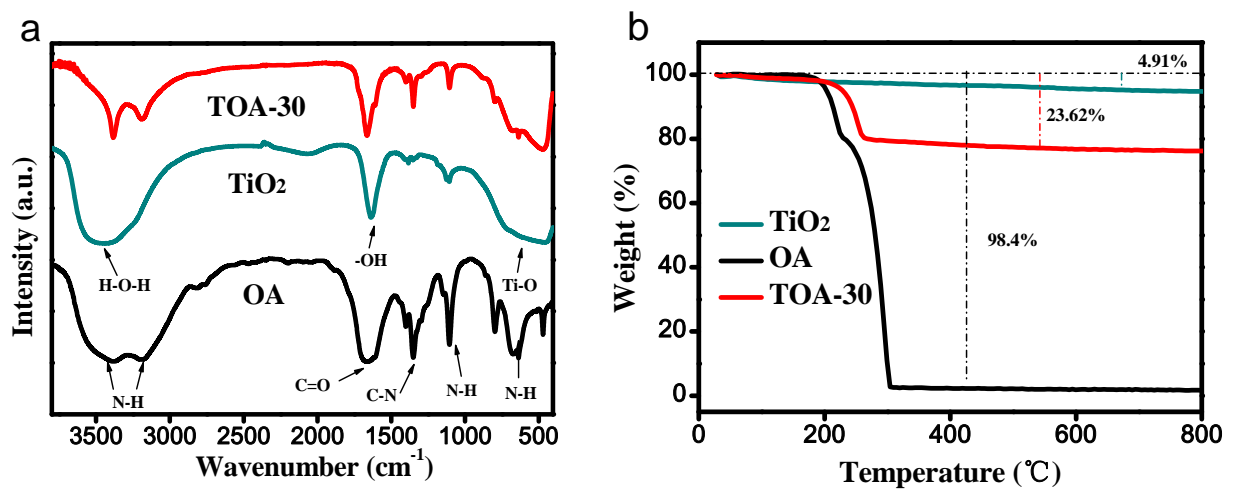

Fig. 4. (a) FT-IR spectra and (b) $\mathrm{TG}$ curves of pure $\mathrm{OA}$, bare $\mathrm{TiO}_{2}$, and $\mathrm{TOA}-30$.

structure was formed between $\mathrm{TiO}_{2}$ and OA. From the TG curves (Fig. 4b), it can be seen that the weight losses of $\mathrm{TiO}_{2}$, OA, and TOA-30 were $4.91 \%, 98.4 \%$, and $23.62 \%$, respectively. The very low weight loss for $\mathrm{TiO}_{2}$ may be ascribed to the removal of the adsorbed water, and the weight losses for $\mathrm{OA}$ and TOA-30 were attributed to the decomposition of OA. The functional groups (C-N and $\mathrm{N}-\mathrm{H}$ ) on the surface and the $23.62 \%$ weight loss of TOA-30 further confirm the successful incorporation of $\mathrm{OA}$ onto the $\mathrm{TiO}_{2}$ surface.

The photocatalytic degradation of $\mathrm{RhB}$ and $\mathrm{MB}$ was performed to further confirm that the OA co-catalyst can effectively promote the photocatalytic activity of the $\mathrm{TiO}_{2}$, and the results are demonstrated in Fig. 5. For bare $\mathrm{TiO}_{2}$, only $20.1 \%$ and $44.9 \%$ of $\mathrm{RhB}$ and $\mathrm{MB}$ are decomposed after irradiation for 60 min and $40 \mathrm{~min}$, respectively. The TOA-30 sample exhibited enhanced photocatalytic performance for the degradation of both RhB and MB. The corresponding apparent rate constants
$\left(\mathrm{K} \mathrm{min}^{-1}\right)$ are presented in Fig. $5 \mathrm{~b}$ and $5 \mathrm{~d}$, and the results indicate that the kinetics for both photocatalytic reactions of $\mathrm{TiO}_{2}$ and TOA-30 follow the Langmuir-Hinshelwood (LH) model. The apparent rate constants $(k$ app $)$ of the photocatalytic degradation of MB and RhB over TOA-30 are $4.80 \times 10^{-2} \mathrm{~min}^{-1}$ and $1.43 \times 10^{-2} \mathrm{~min}^{-1}$, respectively, which are 2.5 and 3.8 times higher than those of pristine $\mathrm{TiO}_{2}$, respectively. The results of the photocatalytic hydrogen evolution and photocatalytic organic-dye degradation confirm that the utilization of the $\mathrm{OA}$ co-catalyst is beneficial for improving the photocatalytic performance.

To study the reusability of the photocatalysts, the TOA-30 hybrid was chosen for the reliability test. Fig. 6a shows the photocatalytic activity of TOA-30 for 5 cycles, where a minor decrease in the degradation efficiency is detected. The slight decrease is due to the loss of some catalyst during the sampling of the MB solution. XRD results (Fig. $6 \mathrm{~b}$ ) show that there is no 

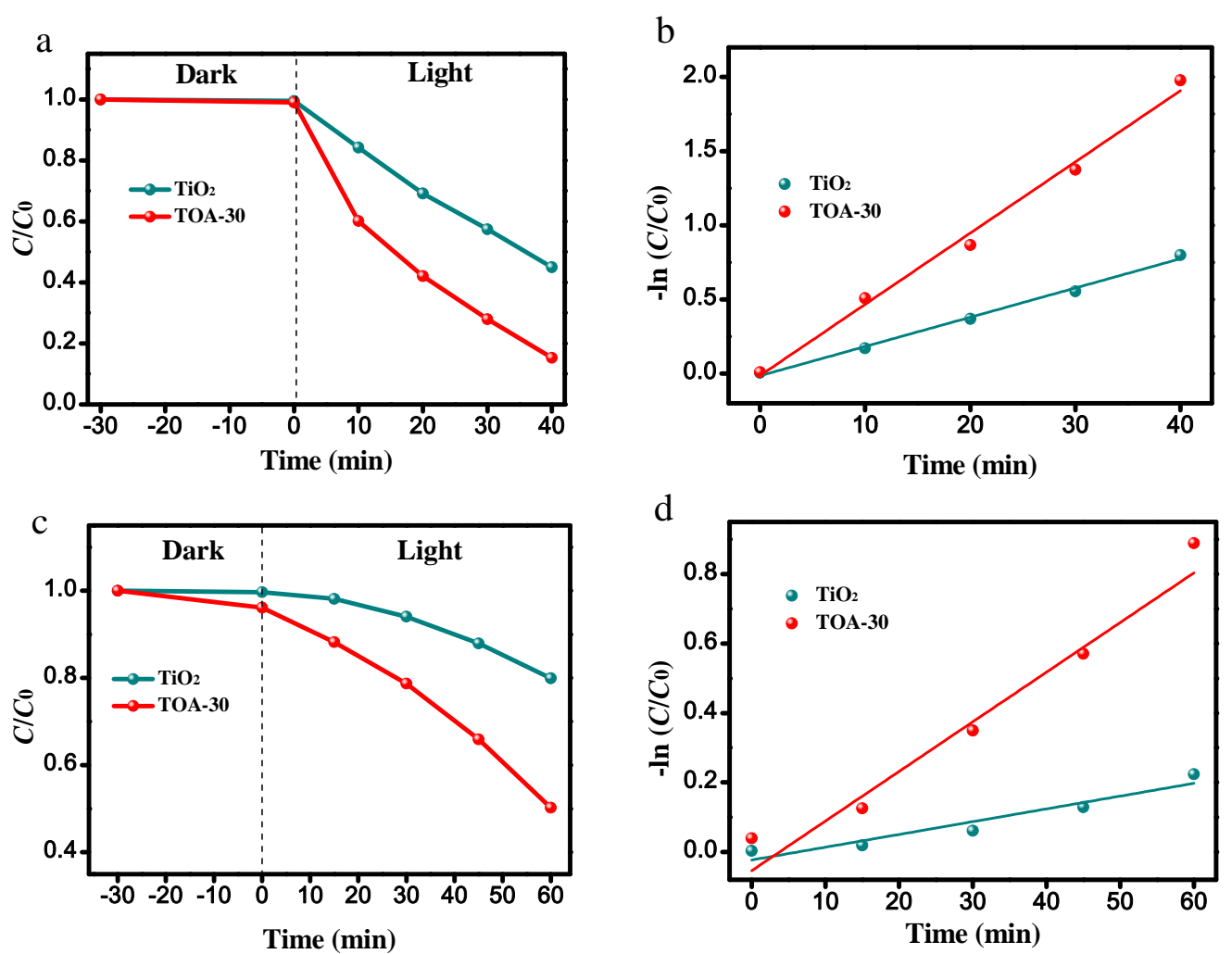

Fig. 5. Variation of (a) $\mathrm{MB}$ and (c) $\mathrm{RhB}$ concentration over $\mathrm{TiO}_{2}$ and $\mathrm{TOA}-30$ under visible-light irradiation; first-order rate constants of $\mathrm{TiO}_{2}$ and TOA-30 for degradation of (b) MB and (d) RhB.
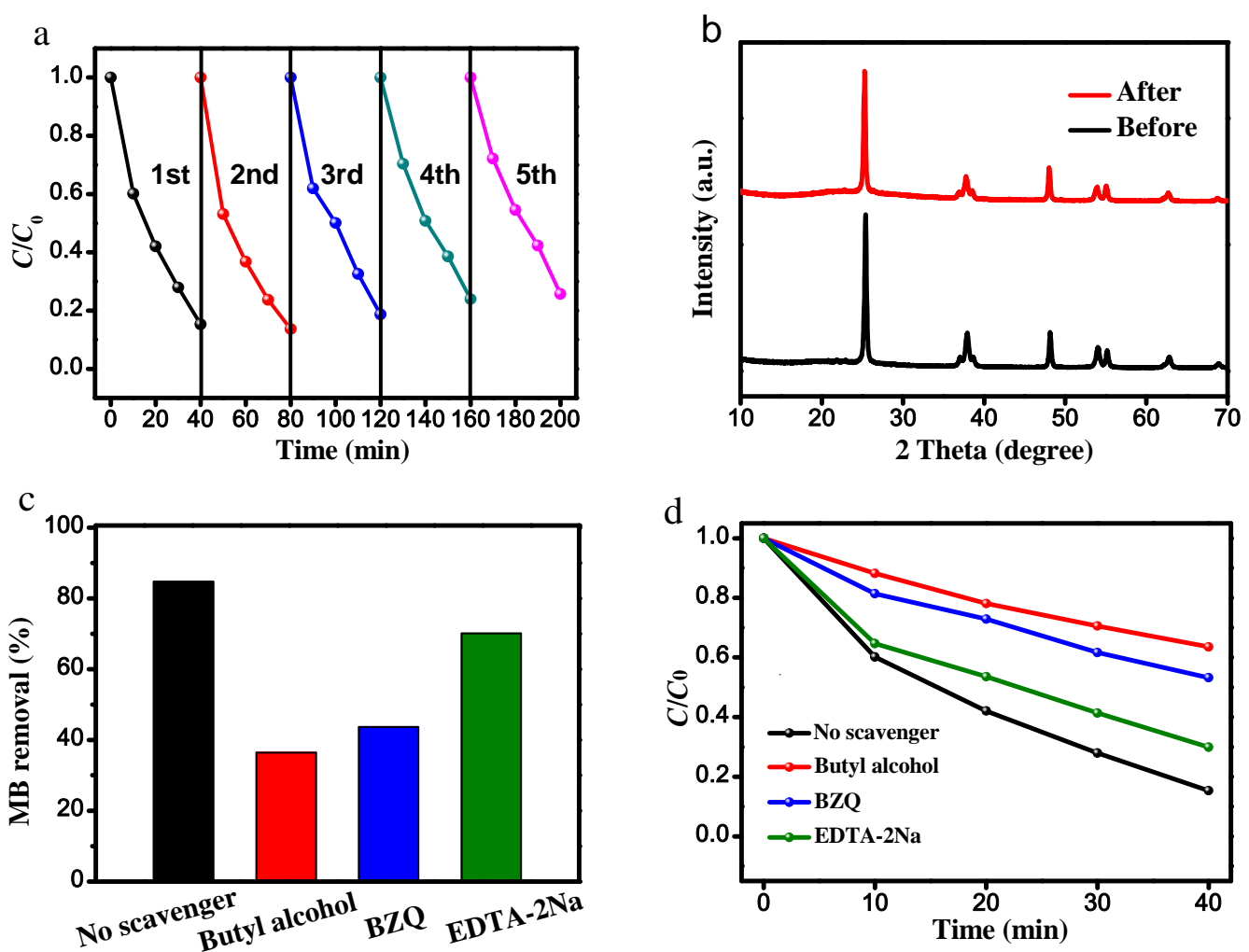

Fig. 6. (a) Recycle tests of photocatalytic degradation of MB over TOA-30 and (b) the corresponding XRD patterns of catalysts before and after photocatalytic test; (c and d) photocatalytic degradation of MB in the presence of different scavengers over TOA-30.

obvious change in the crystal structure of the TOA-30 sample after the photocatalytic reaction, indicating its acceptable chemical stability.

It is generally accepted that free radicals, such as hydroxyl 
radicals $(\bullet \mathrm{OH})$, holes $\left(\mathrm{h}^{+}\right)$, and superoxide radicals $\left(\bullet \mathrm{O}_{2}^{-}\right)$, play a fundamental role in the photocatalytic degradation of dyes $[50,51]$. Free-radical trapping experiments were performed to detect the main active radicals during photodegradation. Different scavengers i.e., butyl alcohol, EDTA-2Na, and $p$-benzoquinone (BZQ) were used to consume $\bullet \mathrm{O}_{2}{ }^{-}, \mathrm{h}^{+}$, and $\bullet \mathrm{OH}$ species, respectively $[52,53]$. It can be seen from Fig. $6 \mathrm{c}$ and $6 \mathrm{~d}$ that the efficiencies of the photocatalytic degradation were lower when scavengers were applied, suggesting that $\bullet^{-} 2^{-}, h^{+}$, and $\bullet \mathrm{OH}$ all contributed to the photocatalytic process. However, the deactivation sequence was butyl alcohol > EDTA-2Na > $\mathrm{BZQ}$, revealing that $\bullet \mathrm{OH}$ played the most important role.

ESR measurements were performed to further elucidate the free radicals involved in the photocatalytic reaction. The ESR spin-trap signals of TOA-30 with DMPO in a methanol solution and an aqueous solution are shown in Fig. 7a and 7b, respectively. Typical ESR signals of $\bullet_{2}{ }^{-}$and $\bullet \mathrm{OH}$ radicals are observed only with visible-light irradiation. Upon irradiation, characteristic peaks of DMPO- $\bullet \mathrm{O}_{2}^{-}$and DMPO- $\bullet \mathrm{OH}$ are both detected in methanol and the aqueous dispersion, illustrating that $\bullet \mathrm{O}_{2}{ }^{-}$and $\bullet \mathrm{OH}$ radicals are generated over TOA-30 during the photocatalytic process. However, for pure $\mathrm{TiO}_{2}$ (Fig. $7 \mathrm{c}$ and $7 \mathrm{~d}$ ), the signals for DMPO- $\bullet \mathrm{O}_{2}{ }^{-}$are strong while those for DMPO- $\bullet \mathrm{OH}$ are very weak, illustrating that the $\bullet \mathrm{O}_{2}{ }^{-}$radicals play the leading role in the photodegradation and that the $\bullet \mathrm{OH}$ radicals are not the main reactive species when pure $\mathrm{TiO}_{2}$ is utilized as the catalyst. The ESR results account for the reason of the enhancement in photocatalytic activity of TOA-30. The intensity of $\mathrm{DMPO}-\bullet \mathrm{O}_{2}^{-}$radical signals for TOA-30 is obviously stronger than that of bare $\mathrm{TiO}_{2}$ (Fig. 7c), which indicates that the concentration of $\bullet \mathrm{O}_{2}{ }^{-}$in TOA-30 is higher than that of $\bullet \mathrm{O}_{2}{ }^{-}$ in pure $\mathrm{TiO}_{2}$. Besides that, for the TOA-30 composite, both $\bullet \mathrm{O}_{2}{ }^{-}$ and $\bullet \mathrm{OH}$ radicals can contribute to the photocatalytic reaction while only $\bullet \mathrm{O}_{2}{ }^{-}$radicals are valid for bare $\mathrm{TiO}_{2}$.

To further investigate the mechanism of the improved photocatalytic activity for $\mathrm{OA}$ co-catalyst loading, the separation efficiency of photogenerated carriers, a crucial step that determines the photocatalytic efficiency, should be understood [54]. The PL spectra, photocurrent, and EIS could provide an insight into the separation of photogenerated charges. The PL spectra of $\mathrm{TiO}_{2}$ and $\mathrm{TOA}-30$ sample were acquired using an excitation with a wavelength of $320 \mathrm{~nm}$ and are shown in Fig. 8a. The PL spectra of $\mathrm{TiO}_{2}$ and TOA-30 sample present an emission peak at about $416 \mathrm{~nm}$ and the emission intensity of the TOA-30 is lower compared to that of bare $\mathrm{TiO}_{2}$. A high separation efficiency of photogenerated charges usually is reflected by a lower PL-peak intensity [55]; the photogenerated carriers in the TOA-30 can be efficiently separated, which is in good agreement with the
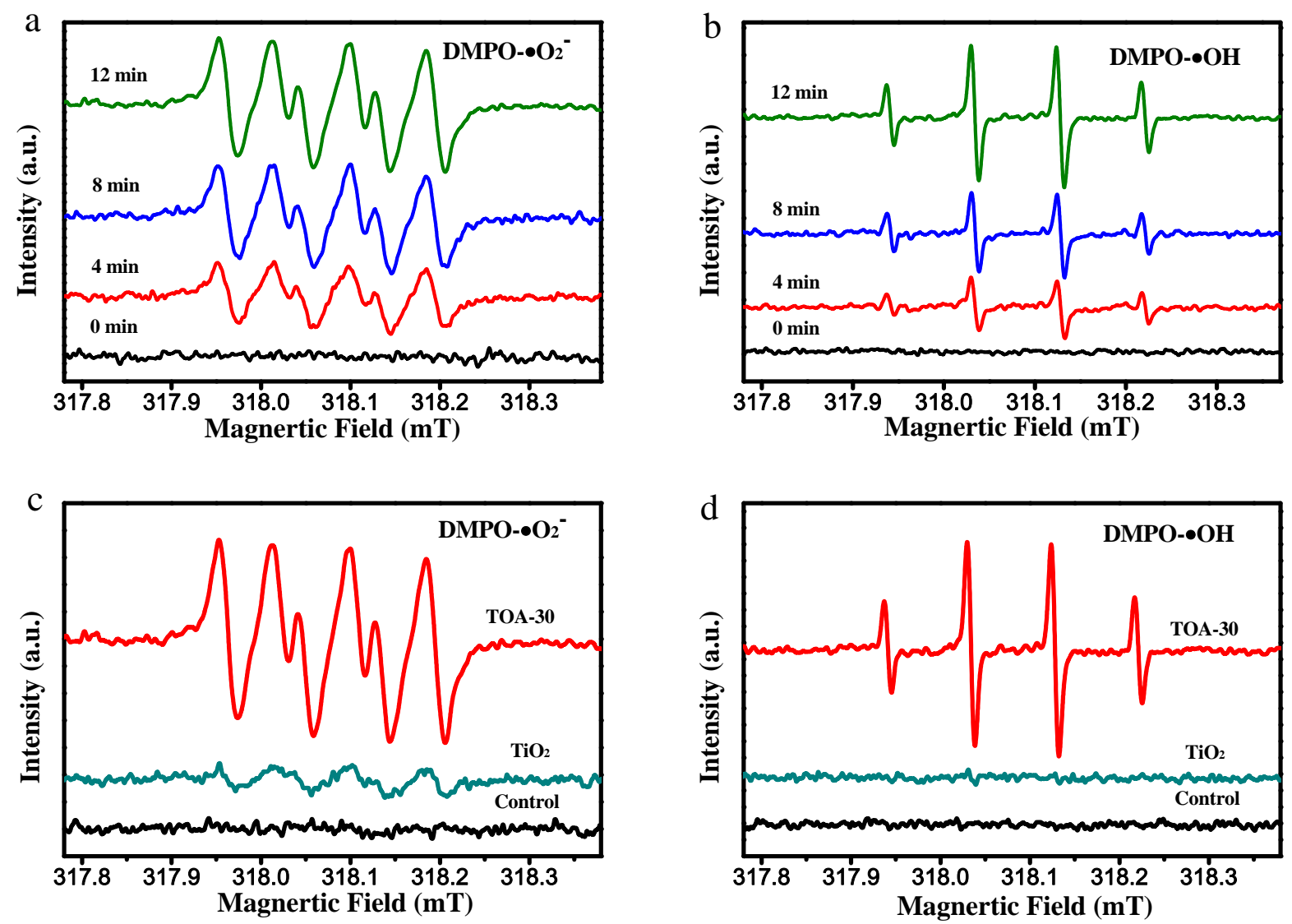

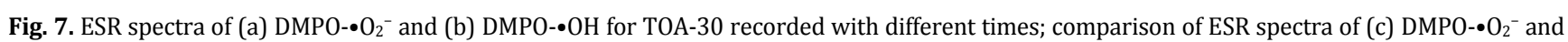
(d) DMPO-•OH for $\mathrm{TiO}_{2}$ and $\mathrm{TOA}-30$ samples. 

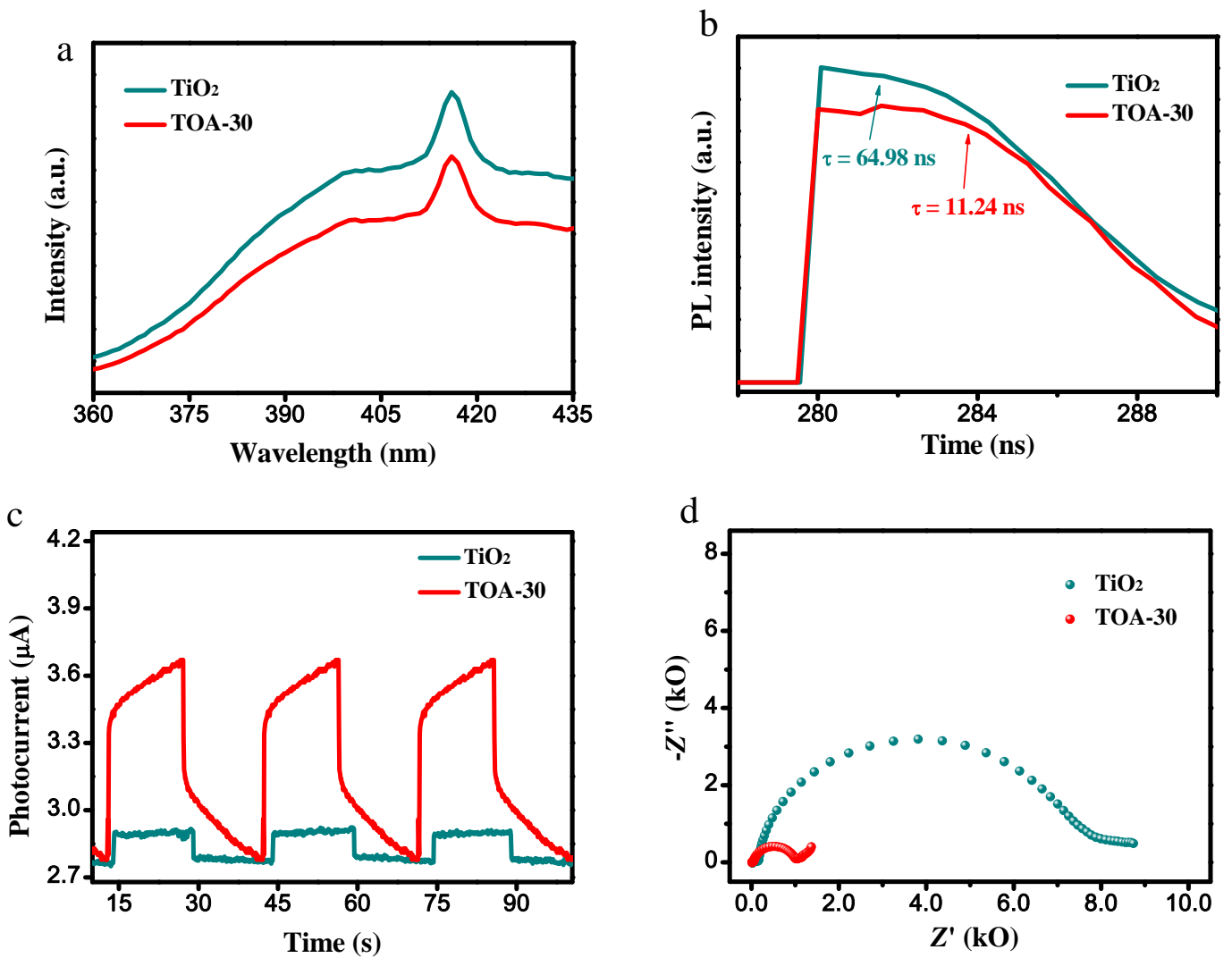

Fig. 8. (a) PL spectra and (b) fluorescence decay curves of $\mathrm{TiO}_{2}$ and $\mathrm{TOA}-30$ excited at $320 \mathrm{~nm}$; (c) photocurrent responses and (d) ESI Nyquist plots of $\mathrm{TiO}_{2}$ and $\mathrm{TOA}-30$ under visible-light irradiation.

results of photocatalytic experiments. Time-resolved PL spectra were also explored to confirm the above results (Fig. 8b). The fluorescence lifetime of TOA-30 is determined to be 11.24 ns, shorter than that of pristine $\mathrm{TiO}_{2}$ (64.98 ns). The curtate lifetime of carriers in TOA-30 implies a fast hole transfer process from $\mathrm{TiO}_{2}$ to $\mathrm{OA}$ and the efficient recombination of the photogenerated charges, which indicates a stepped-up charge transfer motivated by employing $\mathrm{OA}$ as a co-catalyst. Photocurrent measurements and EIS were further utilized to study the kinetics of charge migration. The transient photocurrent responses of the $\mathrm{TiO}_{2}$ and the TOA-30 sample are shown in Fig. 8c; they are steady and reproducible after three cycles. TOA-30 exhibits a higher photocurrent response compared to pure $\mathrm{TiO}_{2}$, suggesting that the separation efficiency of photogenerated carriers is enhanced by the presence of the OA co-catalyst. The results of EIS shown in Fig. 8d further confirm this conclusion; it can be clearly seen that the arc-radius diameter of the TOA-30 sample is much smaller than that of $\mathrm{TiO}_{2}$. The smaller radius of the Nyquist circle represents the lower charge-transfer resistance [56,57], indicating that TOA-30 undergoes rapid interfacial charge migration and fast charge separation. The accelerated charge transfer in the $\mathrm{TiO}_{2}-\mathrm{OA}$ composite improves the photocatalytic activity.

To better understand the underlying mechanism for the optimized photocatalytic performance of the $\mathrm{TiO}_{2}-\mathrm{OA}$ hybrid, it is necessary to study the band-energy structure to explain the generation of free radicals. The UV-vis spectra of $\mathrm{TiO}_{2}$ and TOA-30 are shown in Fig. 9a. The absorption band edge of $\mathrm{TiO}_{2}$ is $425 \mathrm{~nm}$ while the absorption band edge of TOA-30 is $450 \mathrm{~nm}$, showing an obvious red shift compared to $\mathrm{TiO}_{2}$. Besides that, an enhanced visible-light response resulting from the chemical interaction between $\mathrm{TiO}_{2}$ and the $\pi$-conjugated structure of $\mathrm{OA}$ is observed [40]. According to the calculated Tauc's plot, the band gaps of $\mathrm{TiO}_{2}$ and TOA-30 are 2.93 and $2.78 \mathrm{eV}$, respectively (Fig. 9b). The narrowed band-gap energy enables TOA-30 to exhibit better solar-light utilization. The valence-band (VB) positions of $\mathrm{TiO}_{2}$ and TOA-30 are determined according to $\mathrm{VB}$ XPS data, and the conduction-band (CB) edge positions are estimated via the equation: $E_{\mathrm{CB}}=E_{\mathrm{VB}}-E_{\mathrm{g}}$ [56]. Finally, the $\mathrm{VB}$ and $\mathrm{CB}$ edge positions of $\mathrm{TiO}_{2}$ are determined to be 2.89 and $-0.03 \mathrm{eV}$ vs. NHE, respectively. The CB and VB edge potentials of TOA-30 are 2.70 and $-0.08 \mathrm{eV}$ vs. NHE, respectively.

Fig. 10 shows a proposed mechanism for the charge-carrier transfer process in the TiO-OA hybrid. The electrons and holes will be generated in the $\mathrm{CB}$ and $\mathrm{VB}$, respectively, of $\mathrm{TiO}_{2}$ under light irradiation. Although both the band structures of $\mathrm{TiO}_{2}$ and TOA-30 satisfy the requirements of generating $\bullet \mathrm{O}_{2}{ }^{-}$and $\bullet \mathrm{OH}$ $\left(E^{0}\left(\mathrm{O}_{2} / \bullet \mathrm{O}_{2}{ }^{-}\right)=-0.046 \mathrm{eV}\right.$ vs. NHE and $E^{0}\left(\bullet \mathrm{OH} / \mathrm{H}_{2} \mathrm{O}\right)=2.68 \mathrm{eV}$ vs. NHE) $[58,59]$, the $\bullet \mathrm{OH}$ of bare $\mathrm{TiO}_{2}$ can hardly be detected in the ESR spectrum due to the fast recombination of the photogenerated carriers. For the $\mathrm{TiO}_{2}-\mathrm{OA}$ hybrid, the holes in the $\mathrm{VB}$ of $\mathrm{TiO}_{2}$ can migrate to the surface of the OA because OA, with its specific $\pi$-conjugated structure, is an excellent material for transporting holes [40]. Therefore, the recombination of photogenerated carriers can be restrained while the electrons in the $\mathrm{CB}$ can be trapped by $\mathrm{Pt}$ co-catalysts in the $\mathrm{H}_{2}$-evolving re- 

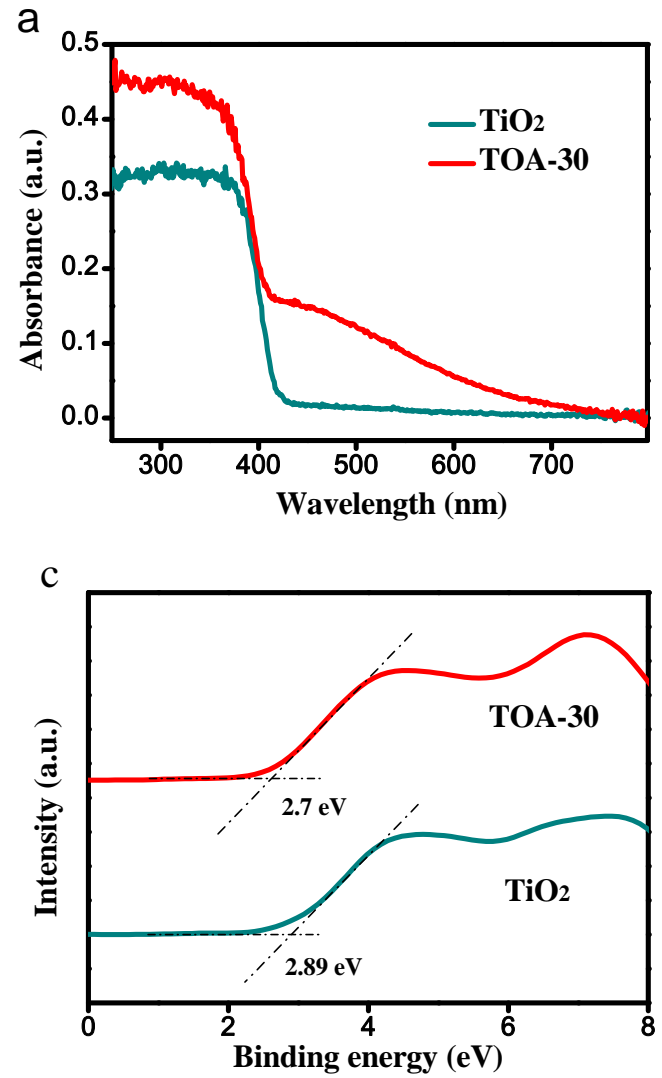

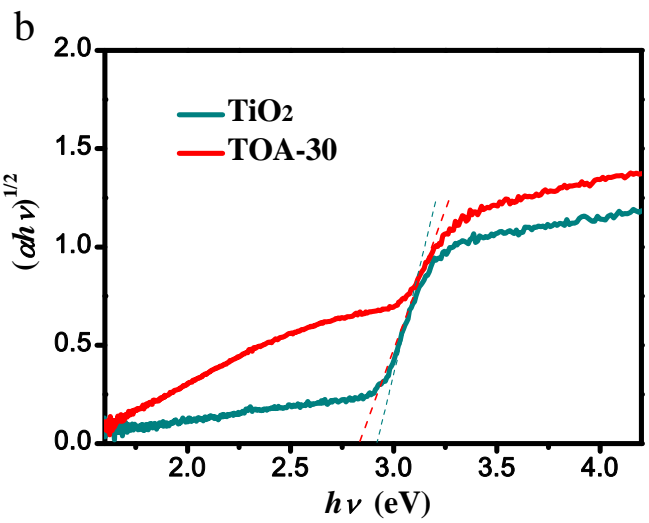

d $\mathrm{V}$ (versus NHE)

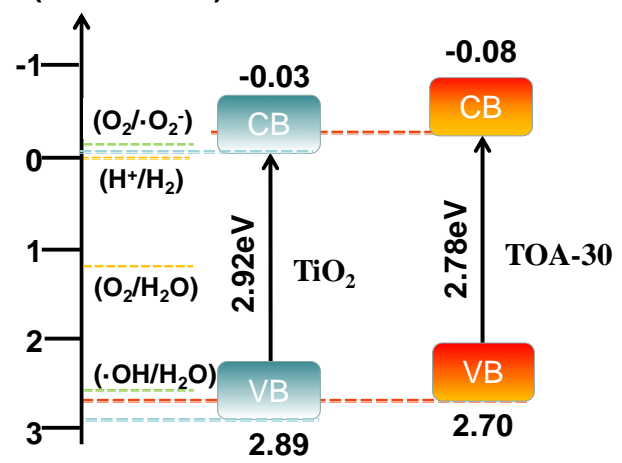

Fig. 9. (a) UV-vis diffuse reflectance spectra, (b) band gaps, and (c) VB-XPS spectra for pure $\mathrm{TiO}_{2}$ and $\mathrm{TOA}-30$; (d) schematic picture of the energy-band structure.

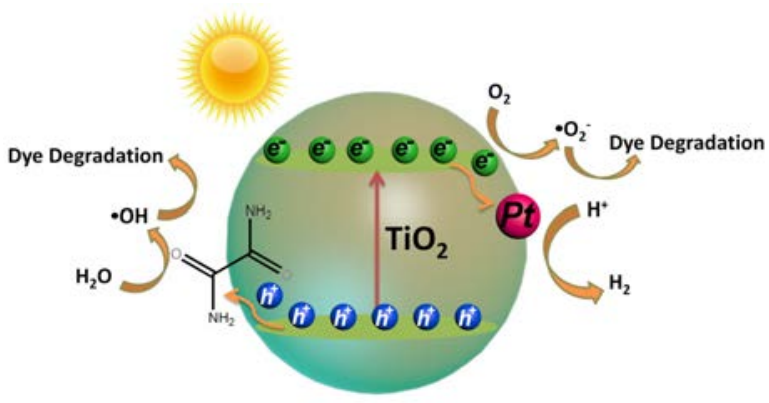

Fig. 10. Proposed photocatalytic mechanism for the $\mathrm{TiO}_{2}-\mathrm{OA}$ hybrid.

action, which can further retard their recombination with holes, and consequently increase the photocatalytic performance.

\section{Conclusions}

In this work, the organic molecule, $\mathrm{OA}$, was chosen as a novel co-catalyst to promote the photocatalytic activity of $\mathrm{TiO}_{2}$. The incorporation of $\mathrm{OA}$ with a unique $\pi$-conjugated structure can provide hole-transfer sites and thus greatly promote the separation and migration of photogenerated carriers from $\mathrm{TiO}_{2}$ to $\mathrm{OA}$. The $\mathrm{H}_{2}$-evolving efficiency and RhB-removal capability of the resultant $\mathrm{TiO}_{2}-\mathrm{OA}$ hybrid with optimal loading of $\mathrm{OA}$ are respectively 2.4 times and 3.8 times higher than those of pristine $\mathrm{TiO}_{2}$ under visible-light irradiation. This work may open up a new way for the construction of efficient photocatalytic systems with a novel organic co-catalyst.

\section{References}

[1] P. F. Wang, T. F. Wu, C. Wang, J. Hou, J. Qian, Y. H. Ao, ACS Sustain. Chem. Eng., 2017, 5, 7670-7677.

[2] H. Tang, S. Chang, G. Tang, W. Liang, Appl. Surf. Sci., 2017, 391, 440-448.

[3] P. Wang, Y. G. Lu, X. F. Wang, H. G. Yu, Appl. Surf. Sci., 2017, 391, 259-266.

[4] L. Tian, X. Z. Xian, X. K. Cui, H. Tang, X. F. Yang, Appl. Surf. Sci., 2018, 430, 301-308.

[5] H. Tang, Y. Fu, S. Chang, S. Xie, G. Tang, Chin. J. Catal., 2017, 38, 337-347.

[6] S. W. Cao, J. Jiang, B. C. Zhu, J. G. Yu, Phys. Chem. Chem. Phys., 2016, $18,19457-19463$.

[7] J. W. Fu, C. B. Bie, B. Cheng, C. J. Jiang, J. G. Yu, ACS Sustain. Chem. Eng., 2018, 6, 2767-2779.

[8] D. F. Xu, B. Cheng, W. K. Wang, C. J. Jiang, J. G. Yu, Appl. Catal. B, 2018, 231, 368-380.

[9] S. W. Cao, H. Li, Y. Li, B. C. Zhu, J. G. Yu, ACS Sustain. Chem. Eng., 2018, 6, 6478-6487.

[10] Y. H. Ao, K. Wang, P. F. Wang, C. Wang, J. Hou, Appl. Catal. B, 2016, 194, 157-168.

[11] M. S. Akple, J. Low, Z. Qin, S. Wageh, A. A. Al-Ghamdi, J. Yu, S. Liu, Chin. J. Catal., 2015, 36, 2127-2134.

[12] K. Qi, B. Cheng, J. Yu, W. Ho, Chin. J. Catal., 2017, 38, 1936-1955.

[13] L. Liang, K. Li, K. Lv, W. Ho, Y. Duan, Chin. J. Catal., 2017, 38, 


\section{Graphical Abstract}

Chin. J. Catal., 2019, 40: 380-389 doi: 10.1016/S1872-2067(18)63166-3

\section{Accelerating photocatalytic hydrogen evolution and pollutant degradation by coupling organic co-catalysts with $\mathrm{TiO}_{2}$}

Jun Shen, Rui Wang, Qinqin Liu*, Xiaofei Yang, Hua Tang, Jin Yang Suzhou Vocational Health College; Jiangsu University;

Nanjing Forestry University

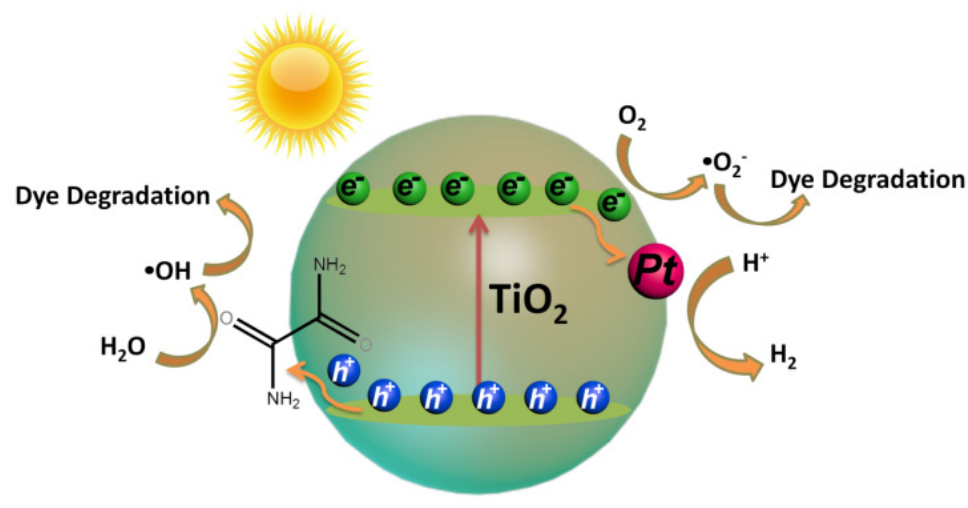

An organic molecule, oxamide, is utilized as a co-catalyst to enhance the photocatalytic $\mathrm{H}_{2}$ evolution and dye-degradation performance of $\mathrm{TiO}_{2}$ nanosheets. Oxamide, which has a unique $\pi$-conjugated structure, can provide hole-transfer sites and thus greatly promote the separation and transfer of photo-generated electron-hole pairs in $\mathrm{TiO}_{2}$.

2085-2093.

[14] L. Ling, L. Liu, Y. Feng, J. Zhu, Z. Bian, Chin. J. Catal., 2018, 39, 639-645.

[15] L. Zheng, X. Yu, M. Long, Q. Li, Chin. J. Catal., 2017, 38, 2076-2084.

[16] C. Zhang, L. Tian, L. Chen, X. L, K. Lv, K. Deng, Chin. J. Catal., 2018, 39, 1373-1383.

[17] K. Yu, C. Zhang, Y. Chang, Y. Feng, Z. Yang, T. Yang, L. L. Lou, S. Liu, Appl. Catal. B, 2017, 200, 514-520.

[18] Y. H. Fu, W. Liang, J. Q. Guo, H. Tang, S. S. Liu, Appl. Surf. Sci., 2018, $430,234-242$.

[19] H. W. Huang, J. J. Lin, G. B. Zhu, Y. X. Weng, X. X. Wang, X. Z. Fu, J. L. Long, Angew. Chem. Int. Ed., 2016, 55, 8314-8318.

[20] A. Meng, J. Zhang, D. Xu, B. Cheng, J. Yu, Appl. Catal. B, 2016, 198, 286-294.

[21] X. Zhang, G. Zuo, X. Lu, C. Tang, S. Cao, M. Yu, J. Colloid Interface Sci, 2017, 490, 774-782.

[22] N. Nie, L. Y. Zhang, J. W. Fu, B. Cheng, J. G. Yu, Appl. Surf. Sci., 2018, $441,12-22$.

[23] Q. L. Xu, B. Cheng, J. G. Yu, Carbon, 2017, 118, 241-249.

[24] J. W. Fu, J. G. Yu, C. J. Jiang, B. Cheng, Adv. Energy Mater., 2018, 8 , 1701503.

[25] S. W. Cao, J. X. Low, J. G. Yu, M. Jaroniec, Adv. Mater., 2015, 27, 2150-2176.

[26] Q. Q. Liu, J. Y. Shen, X. F. Yang, T. R. Zhang, H. Tang, Appl. Catal. B, 2018, 232, 562-573.

[27] B. C. Zhu, L. Y. Zhang, B. Cheng, J. G. Yu, Appl. Catal. B, 2018, 224, 983-999.

[28] P. Zhou, J. G. Yu, M. Jaroniec, Adv. Mater., 2014, 26, 4920-4935.

[29] L. P. Zhang, G. H. Wang, Z. Z. Xiong, H. Tang, C. J. Jiang, Appl. Surf. Sci., 2018, 436, 162-171.

[30] B. C. Zhu, J. F. Zhang, C. J. Jiang, B. Cheng, J. G. Yu, Appl. Catal. B, 2017, 207, 27-34.

[31] R. A. Rather, S. Singh, B. Pal, Appl. Catal. B, 2017, 213, 9-17.
[32] C. Marchal, T. Cottineau, M. G. Méndez-Medrano, C. Colbeau-Justin, V. Caps, V. Keller, Adv. Energy Mater., 2018, 8, 1702142.

[33] J. J. Li, S. C. Cai, E. Q. Yu, B. Weng, X. Chen, J. Chen, H. P. Jia, Y. J. Xu, Appl. Catal. B, 2018, 233, 260-271.

[34] C. Yang, Z. Y. Zhao, Comp. Mater. Sci., 2018, 151, 160-173.

[35] A.Y. Meng, S. Wu, B. Cheng, J. G. Yu, J. S. Xu, J. Mater. Chem. A, 2018, 6, 4729-4736.

[36] S. W. Cao, B. J. Shen, T. Tong, J. W. Fu, J. G. Yu, Adv. Funct. Mater., 2018, 28, 1800136.

[37] K. K. Paul, N. Sreekanth, R. K. Biroju, T. N. Narayanan, P. K. Giri, Sol. Energy Mater. Sol. Cells, 2018, 185, 364-374.

[38] G. Yang, H. Ding, J. J. Feng, Q. Hao, S. J. Sun, W. H. Ao, D. M. Chen, Sci. Rep., 2017, 7, 14594.

[39] X. Y. Feng, P. F. Wang, J. Hou, J. Qian, Y. H. Ao, J. Harzard. Mater., 2018, 344, 196-205.

[40] L. Liu, L. Ding, Y. Liu, W. An, S. Lin, Y. Liang, W. Cui, Appl. Catal. B, 2017, 201, 92-104.

[41] S. Kim, G. H. Moon, G. Kim, U. Kang, H. Park, W. Choi, J. Catal., 2017, 346, 92-100.

[42] H. J. Hou, X. H. Zhang, D. K. Huang, X. Ding, S. Y. Wang, X. L. Yang, S. Q. Li, Y. G. Xiang, H. Chen, Appl. Catal. B, 2017, 203, 563-571.

[43] K. Chen, Z. Jiang, J. Qin, Y. Jiang, R. Li, H. Tang, X. Yang, Ceram. Int., 2014, 40, 16817-16823.

[44] X. Yang, J. Qin, Y. Jiang, K. Chen, X. Yan, D. Zhang, R. Li, H. Tang, Appl. Catal. B, 2015, 166, 231-240.

[45] J. Li, M. Zhang, Q. Li, J. Yang, Appl. Surf. Sci., 2017, 391, 184-193.

[46] R. Vinoth, P. Karthik, K. Devan, B. Neppolian, M. Ashokkumar, Ultrason. Sonochem., 2017, 35, 655-663.

[47] W. Dong, F. Pan, L. Xu, M. Zheng, C. H. Sow, K. Wu, G. Q. Xu, W. Chen, Appl. Surf. Sci., 2015, 349, 279-286.

[48] R. Shi, Z. Li, H. Yu, L. Shang, C. Zhou, G. I. N Waterhouse, L. Wu, T. Zhang, ChemSusChem, 2017, 22, 4650-4656

[49] T. Yang, J. Peng, Y. Zheng, X. He, Y. Hou, L. Wu, X. Fu, Appl. Catal. B, 
2018, 221, 223-234.

[50] Z. Lu, L. Zeng, W. Song, Z. Qin, D. Zeng, C. Xie, Appl. Catal. B, 2017, 202, 489-499.

[51] D. Xu, B. Cheng, S. Cao, J. Yu, Appl. Catal. B, 2015, 164, 380-388.

[52] Y. Hong, Y. Jiang, C. Li, W. Fan, X. Yan, M. Yan, W. Shi, Appl. Catal. B, 2016, 180, 663-673.

[53] F. Chen, Q. Yang, X. Li, G. Zeng, D. Wang, C. Niu, J. Zhao, H. An, T. Xie, Y. Deng, Appl. Catal. B, 2017, 200, 330-342.

[54] Y. He, L. Zhang, M. Fan, X. Wang, M. L. Walbridge, Q. Nong, Y. Wu, L. Zhao, Sol. Energy Mater. Sol. Cells, 2015, 137, 175-184.
[55] L. Tian, X. Yang, Q. Liu, F. Qu, H. Tang, Appl. Surf. Sci., 2018, 455, 403-409.

[56] W. Liu, J. Shen, X. Yang, Q. Liu, H. Tang, Appl. Surf. Sci., 2018, 456, 369-378.

[57] W. Liu, J. Shen, Q. Liu, X. Yang, H. Tang, Appl. Surf. Sci., 2018, 462, 822-830.

[58] Y. Fu, Z. Li, Q. Liu, X. Yang, H. Tang, Chin. J. Catal., 2017, 38, 2160-2170.

[59] R. Hao, G. Wang, C. Jiang, H. Tang, Q. Xu, Appl. Surf. Sci., 2017, 411, 400-410.

\section{利用有机助剂提高 $\mathrm{TiO}_{2}$ 光催化产氢和降解性能

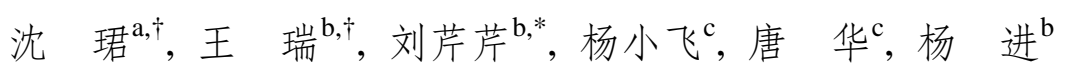 a苏州卫生职业技术学院药学院, 江苏苏州215009

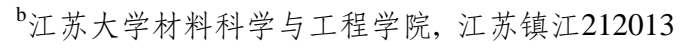 \\ c南京林业大学理学院化学系, 江苏南京212237}

摘要: 采用助催化剂加速光催化材料中空穴-电子对的分离提高光催化效率的有效方法. 本文以有机分子草酰胺 $(\mathrm{OA})$ 作为 新型助催化剂来促进 $\mathrm{TiO}_{2}$ 光催化材料的光生载流子分离, 从而增强其光催化 $\mathrm{H}_{2}$ 释放和染料降解性能. 最佳 $\mathrm{TiO}_{2}-\mathrm{OA}$ 复合光 催化剂上 $\mathrm{H}_{2}$ 的析出和罗丹明B的光催化效率分别达到 $2371 \mu \mathrm{mol} \mathrm{g}^{-1} \mathrm{~h}^{-1}$ 和1.43 $\times 10^{-2} \mathrm{~min}^{-1}$, 分别是 $\mathrm{TiO}_{2}$ 的 2.4 和3.8倍. 系统研 究了光催化增强的可能机理, 并提出 $\mathrm{OA}$ 凭借其 $\pi$-共轭结构作为助催化剂, 不仅增强了 $\mathrm{TiO}_{2}$ 的光吸收, 而且促进了空穴转 移, 因而达到了加速电荷分离的效果.

利用湿化学法合成了 $\mathrm{TiO}_{2}-\mathrm{OA}$ 光催化材料, 并采用X射线衍射(XRD)、X射线光电子能谱(XPS)、扫描电子显微镜 (SEM)、透射电子显微镜(TEM)、红外光谱(FT-IR)以及紫外-可见漫反射光谱(UV-vis)等表征方法对该催化剂的结构特征、 微观形貌和光学性能进行分析, 并研究了 $\mathrm{TiO}_{2}-\mathrm{OA}$ 复合材料的光催化性能. SEM和TEM结果表明, $\mathrm{TiO}_{2}-\mathrm{OA}$ 呈方形, 尺寸约 为 $30 \mathrm{~nm}$. $\mathrm{OA}$ 含量为 $30 \mathrm{wt} \%$ 的 $\mathrm{TiO}_{2}-\mathrm{OA}$ 样品在用于制氢的光催化水分解反应中表现最佳. 同时研究了 $\mathrm{TiO}_{2}-\mathrm{OA}$ 光催化剂的 光催化机理, 用对苯醌、乙二胺四乙酸二钠和正丁醇进行了自由基捕捉剂实验. 结果表明, 羟基自由基在降解有机染料过 程中起主要作用. 通过光电流测试、材料价带导带位置计算以及 $\cdot \mathrm{O}_{2}$ 和 $\cdot \mathrm{OH}$ 定量实验并结合文献分析认为, 掺入具有独特 $\pi$ 共轭结构的 $\mathrm{OA}$ 可以提供空穴转移位点, 从而极大地促进 $\mathrm{TiO}_{2}$ 和 $\mathrm{OA}$ 之间光生电子-空穴的分离和转移. 本工作可能为构建 具有新型有机助催化剂的高效光催化体系开辟了一条新途径.

关键词: 二氧化钛; 草酰胺; 助催化剂; 光催化; 制氢; 染料降解

收稿日期: 2018-08-31. 接受日期: 2018-09-21. 出版日期: 2019-03-05.

†共同第一作者.

*通讯联系人. 电话: (0511)88790191; 传真: (0511)88790195; 电子信箱: liu_qin_qin@126.com 基金来源：国家自然科学基金(51672113，51602132); 江苏省六大人才高峰计划(2015-XCL-026); 江苏省自然科学基金 (BK20171299); 江苏大学 “青年骨干教师培训工程”青年学术带头人培育人选(5521220009); 江苏省卫生计生委2016年度青年科 研课题(Q201609).

本文的电子版全文由Elsevier出版社在ScienceDirect上出版(http://www.sciencedirect.com/science/journal/18722067). 